\title{
Assessment on Oral Health Knowledge, Attitude, and Behaviour and its Association with Sociodemographic and Habitual Factors of South Indian Population
}

\author{
Siddharthan Selvaraj ${ }^{\circledR}$, Nyi Nyi Naing ${ }^{1}$, Nadiah Wan-Arfah²@ ${ }^{\circledR}$, Mauro Henrique Nogueira \\ Guimarães de Abreus
}

'Faculty of Medicine, Medical Campus, Universiti Sultan Zainal Abidin, Kuala Terengganu, Terengganu, Malaysia.

${ }^{2}$ Faculty of Health Sciences, Universiti Sultan Zainal Abidin, Kuala Terengganu, Terengganu, Malaysia.

3Department of Community and Preventive Dentistry, School of Dentistry, Federal University of Minas Gerais, Belo Horizonte, MG, Brazil.

Correspondence: Nyi Nyi Naing, Faculty of Medicine, Medical campus, Universiti Sultan Zainal Abidin, Kuala Terengganu, Terengganu 20400, Malaysia. E-mail: syedhatim@unisza.edu.my

Academic Editor: Alessandro Leite Cavalcanti

Received: 14 July 2021 / Review: 08 August 2021 / Accepted: 15 August 2021

How to cite: Selvaraj S, Naing NN, Wan-Arfah N, Abreu MHNG. Assessment on oral health knowledge, attitude, and behaviour and its association with sociodemographic and habitual factors of South Indian population. Pesqui Bras Odontopediatria Clín Integr. 2021; 21:e0135. https://doi.org/10.1590/pboci.2021.159

\begin{abstract}
Objective: To assess the oral health knowledge, attitude, behaviour, and its association with sociodemographic and habitual factors among South Indian Population. Material and Methods: A total of 288 adults living in a residential community situated in Chennai were selected by systematic random sampling method participated in this cross-sectional study. Data collection was carried out using a validated questionnaire. Results: About $97.9 \%$ of the participants in our study had good knowledge, $33.3 \%$ had a positive attitude and $48.2 \%$ had adequate oral health behaviour. Sociodemographic and habitual factors like diet $(\mathrm{p}=0.006)$, education $(\mathrm{p}=0.009)$, and employment $(\mathrm{p}=0.003)$ were significantly associated with knowledge. On the other hand, diet $(\mathrm{p}=0.012)$ was the only factor significantly associated with attitude. Ownership of house $(\mathrm{p}=0.030)$ was significantly associated with behaviour and no factor was associated with all three KAB profiles. Absence of correlation were identified between Knowledge-Attitude $(r=0.11$, $\mathrm{p}=0.23)$, Knowledge-Behaviour $(\mathrm{r}=-0.037, \mathrm{p}=0.68)$ and Attitude-Behaviour $(\mathrm{r}=0.01, \mathrm{p}=0.94)$. Conclusion: It has been found a massive number of participants possessed a high knowledge level towards oral health. On the other hand, less than half of the participants had a positive attitude and adequate behaviour towards oral health. No positive linear correlation was seen among knowledge, attitude, and behaviour towards oral health.
\end{abstract}

Keywords: Oral Health; Knowledge; Attitude; Health Behavior. 


\section{Introduction}

Oral health-related conditions among Indian population have been a big issue in every Indian state for the past 10 years. Even basic oral health education has become unachievable to major Indian population [1]. From the global population, $17.31 \%$ comprises Indian individuals, where one out of six people of the global population live in India. It has been evident that people of India have a significant disparity in oral health care, $95 \%$ of Indians have dental-related conditions [2]. India is a fast-developing vast nation, where people of India give slightest importance towards oral health with increased oral conditions presence [1]. Various external factors like sociodemographic factors like age, gender, ethnicity, marital status and religion play a major role in oral hygiene and oral conditions among Indian adults. In addition, it has been stated that socioeconomic status of an individual also end up in poor oral hygiene. An individual's income and education determine the level of importance a person gives towards oral hygiene. Habitual factors like smoking and alcohol consumptions play a significant role in an individual's oral hygiene; though these relationships between various modifiable factors of south Indian adults on oral health have been studied earlier, there is a need for assessment in a vast manner [3].

Adequate oral hygiene of an individual helps enhance the self-esteem of an individual, leading to a better quality of life [4]. Individuals' oral health concern depends on an individual's awareness and strongly influence the effect on oral health status [5] and it has been reported that majority (75.6\%) of Indian adults possess good oral health knowledge level, less than half $(44.78 \%)$ had a positive attitude towards oral health and nearly half $(47.56 \%)$ of the participants had adequate behaviour towards oral health [6].

Oral health information is still very much restricted among Indian people [7]. However, it is well known that major oral health-related conditions can be restrained with suitable awareness [8]. Therefore, dental professionals can act as oral health educators and play an ideal role in educating every individual about oral health that might influence individual and community levels. Nevertheless, prior to educating the individuals, it is good to know the individual's oral health knowledge level, attitude, and behaviour [9].

For a developing nation like India, the rate of general language literacy is relatively low and awareness towards oral health is much lower [10]. Health education based oral health promotion strategy will be an ideal choice for India instead of endorsing conventional oral health promotion methods, which are unsuccessful to attain alteration that is being followed among developed nations [11].

Substandard maintenance of oral hygiene of an individual is mainly because of poor knowledge or carelessness. Individuals who have gained relevant instructions on oral hygiene, consistently following it manifest positive signs [12]. Individuals who have recognized the knowledge of their personal control over oral health have a high possibility of taking up self-care behaviour. Attitude towards oral health of an individual impacts oral self-care habits and affects the ability of an individual's care towards teeth [13]. As dentists play a vital role in educating community on oral hygiene, it is essential to know the oral health knowledge, attitude, and behaviour at the community level. Our study aimed to assess the oral health knowledge, attitude, behaviour, and its association with sociodemographic and habitual factors of South Indian Population.

\section{Material and Methods}

\section{Study Design}

This cross-sectional study was carried out among adults from South India who live in Chennai. 
Sample Size and Sampling Design

A total of 288 adults took part in our study and were selected by systematic random sampling method.

The interval of samples was obtained by dividing the total size of the population by the desired sample size needed for the study. Based on a recommendation by Selvaraj et al., sample size was estimated in our study [14]. The participants resided in a residential community in Chennai, and those who fulfilled the inclusion criteria were considered. Individuals above the age of 18, individuals who can read and write English, and volunteered themselves to be a part of our research were included. Study samples were picked in a fixed manner. To add upon, individuals who were physically, mentally, or legally incapacitated, so that informed consent to treat cannot be obtained were not included in our study.

\section{Data Collection Procedures}

Data collection was carried out in February 2021. As the world is going through a pandemic situation due to COVID-19, dentists have a high potential to get COVID-19 [15] as oral cavity acts as a pool for various respiratory pathogens [16]. Data collection was done by utilizing proper protective equipment like a face mask, face shield, and SOP guidelines given by the health department of Tamil Nadu government was followed in a rightful manner. Then, the individuals were asked to answer the validated questionnaire [14]. It took nearly 10 minutes to complete the questionnaire.

\section{Content of the Questionnaire}

A new questionnaire was developed in our study to satisfy the quality, attain the objective of our study, and make the study effective. Firstly, exploratory factor analysis was carried out in our previous study to validate our questionnaire. Furthermore, confirmatory factor analysis of our oral health KAB questionnaire had ideal goodness-of-fit values and had good convergent and discriminant validity. The results of our confirmatory factor analysis had statistically significant values [14].

The validated questionnaire comprised of 26 items to assess knowledge (Aetiology, clinical manifestation, treatment, symptoms, preventive measures on oral health), attitude (Individuals' attitudes towards oral health based on health belief model), and behaviour (Various actions towards oral hygiene that might have a good or ill effect on oral health) towards oral health among south Indian adults, contents of the questionnaire can be found in Table 1.

Table 1. Oral health KAB Questionnaire.

\begin{tabular}{|c|c|c|}
\hline Knowledge (11 Questions) & Attitude (8 Questions) & Behaviour (7 Questions) \\
\hline $\begin{array}{l}\text { 1. There are two sets of teeth during } \\
\text { lifetime }\end{array}$ & 1. Brushing teeth twice a day improves oral hygiene & $\begin{array}{l}\text { 1. I give importance to my teeth as } \\
\text { much as any part of my body }\end{array}$ \\
\hline 2. Tooth infection causes gum bleeding & $\begin{array}{l}\text { 2. Keeping your teeth clean and healthy is beneficial } \\
\text { to your health }\end{array}$ & 2. I have sensitive teeth \\
\hline $\begin{array}{l}\text { 3. Replacement of missing tooth } \\
\text { improves oral hygiene }\end{array}$ & 3. Improper brushing leads to gum disease & 3. I brush my tooth twice daily \\
\hline $\begin{array}{l}\text { 4. The dental caries of deciduous teeth } \\
\text { need not be treated }\end{array}$ & 4. Sweet's retention leads to tooth decay & $\begin{array}{l}\text { 4. I use teeth to open cap of bottled } \\
\text { drink }\end{array}$ \\
\hline $\begin{array}{l}5 \text {. Bacteria is one of the reasons to cause } \\
\text { gingival problems }\end{array}$ & $\begin{array}{l}\text { 5. Brushing with fluoridated toothpaste prevent } \\
\text { tooth decay }\end{array}$ & $\begin{array}{l}\text { 5. I experience toothache while } \\
\text { chewing food }\end{array}$ \\
\hline $\begin{array}{l}\text { 6. Fizzy soft drinks affect the teeth } \\
\text { adversely }\end{array}$ & $\begin{array}{l}\text { 6. Dentists care only about treatment \& not } \\
\text { prevention }\end{array}$ & $\begin{array}{l}\text { 6. I have bleeding gums during } \\
\text { brushing }\end{array}$ \\
\hline 7. Loss of teeth can interfere with speech & 7. Gum bleeding denotes gum infection & 7. I do routine dental check-up \\
\hline $\begin{array}{l}\text { 8. Irregularly placed teeth can be moved } \\
\text { into correct position by dental treatment }\end{array}$ & 8. Scaling is harmful for gums & \\
\hline
\end{tabular}


10. Tobacco chewing, or smoking can cause oral cancer

11. White patches on teeth are called

dental plaque

Knowledge Towards Oral Health

The knowledge part of the questionnaire comprises 11 questions that were based on fundamental knowledge towards oral health practices and the aim of oral health maintenance. The questions were multiplechoice and participants were informed to choose the response which they felt was correct. The responses regarding knowledge were given a score of 1 for the right answer and o (zero) for the wrong answer.

\section{Attitude Towards Oral Health}

The questionnaire's attitude part comprises eight questions based on the attitude towards oral health maintenance. First, five-response categories were assigned to the statements associated with the attitude: strongly agree, agree, no opinion, disagree, and strongly disagree. The categories strongly agree and agree were combined to yield the measure of agreement. In contrast, the categories no opinion, disagree, and strongly disagree were combined to yield the measure of disagreement. Then, considering positive attitude (score 1) and negative attitude (score 0) for each statement, a sum score of attitudes was calculated for each participant.

\section{Behaviour Towards Oral Health}

The questionnaire's behaviour part comprises seven questions based on the fundamental behaviour or actions that the adults take to maintain their oral health. First, five-response categories were assigned to the statements associated with the behaviour: never, seldom, occasionally, very often, and always. The categories seldom, occasionally, very often, and always were combined to yield the measure of agreement, whereas the category never was considered the measure of disagreement. Then, considering adequate behaviour (score 1) and inadequate behaviour (score 0) for each statement, a sum score of behaviour was calculated for each participant.

\section{Statistical Analysis}

Descriptive analysis was carried out to calculate the frequency and percentages of the variables to assess the sociodemographic and habits profile. As our data did not meet the assumptions, Mann-Whitney $\mathrm{U}$ test and Kruskal Wallis test were carried out to investigate the association of sociodemographic and habitual factors with oral health knowledge, attitude, and behaviour profile. Spearman's rank correlation analysis was carried out to identify the correlation coefficient between knowledge, attitude, and behaviour towards oral health. The p-value of $<0.05$ was taken statistically significant.

\section{Ethical Clearance}

Ethics approvals for our study were received from the University Sultan Zainal Abidin Human Research Ethics Committee (Protocol No: UniSZA/UHREC/2020/197) and RIPON independent ethics committee from India (Protocol No: RIPON/NOV30/2020/800). Informed consent was obtained prior to collecting the data from the participants of the study. A brief explanation was given to the participants about the purpose of our study, procedures and confidentiality of the data collected. 


\section{Results}

A total of 288 participants were included in this study, of which 147 (51\%) were male. The majority of the participants belong to $35-44$ years 84 (29.1\%) and $66.7 \%$ were married. In addition, 237 (82.2\%) participants belong to Hindu religion (Table 2).

Table 2. Sociodemographic and habits profile of the adult population.

\begin{tabular}{|c|c|c|}
\hline Variables & $\mathbf{N}$ & $\%$ \\
\hline \multicolumn{3}{|l|}{ Gender } \\
\hline Male & 147 & 51.0 \\
\hline Female & 141 & 49.0 \\
\hline \multicolumn{3}{|l|}{ Age (in Years) } \\
\hline $18-24$ & 68 & 23.6 \\
\hline $25-34$ & 65 & 22.6 \\
\hline $35-44$ & 84 & 29.1 \\
\hline$\geq 45$ & 71 & 24.7 \\
\hline \multicolumn{3}{|l|}{ Marital Status } \\
\hline Married & 192 & 66.7 \\
\hline Single & 96 & 33.3 \\
\hline \multicolumn{3}{|l|}{ Religion } \\
\hline Hindu & 237 & 82.2 \\
\hline Muslim & 15 & 5.2 \\
\hline Christian & 30 & 10.6 \\
\hline Others & 6 & 2.0 \\
\hline \multicolumn{3}{|l|}{ Ethnicity } \\
\hline Tamil & 264 & 91.6 \\
\hline Others & 24 & 8.4 \\
\hline \multicolumn{3}{|l|}{ Diet } \\
\hline Vegetarian & 32 & 11.1 \\
\hline Non-Vegetarian & 52 & 18.2 \\
\hline Mixed & 204 & 70.7 \\
\hline \multicolumn{3}{|l|}{ Smoking } \\
\hline Yes & 40 & 13.9 \\
\hline No & 248 & 86.1 \\
\hline \multicolumn{3}{|l|}{ Alcohol consumption } \\
\hline Yes & 35 & 12.2 \\
\hline No & 253 & 87.8 \\
\hline \multicolumn{3}{|l|}{ Education } \\
\hline Illiterate & 7 & 2.6 \\
\hline Primary & 12 & 4.7 \\
\hline High school & 93 & 31.6 \\
\hline University & 176 & 61.1 \\
\hline \multicolumn{3}{|l|}{ Employment status } \\
\hline Employed & 186 & 64.6 \\
\hline Unemployed & 23 & 8.0 \\
\hline Student & 46 & 16.0 \\
\hline Homemaker & 33 & 11.4 \\
\hline \multicolumn{3}{|l|}{ Income } \\
\hline Below 10K₹ & 98 & 34.1 \\
\hline 10K₹-2OK₹ & 50 & 17.3 \\
\hline 20K₹-30K₹ & 72 & 25.0 \\
\hline Above 30K₹ & 68 & 23.6 \\
\hline \multicolumn{3}{|l|}{ House Ownership } \\
\hline Owned & 178 & 61.8 \\
\hline Rented & 110 & 38.2 \\
\hline \multicolumn{3}{|l|}{ Own Vehicle } \\
\hline Yes & 180 & 62.5 \\
\hline No & 108 & 37.5 \\
\hline
\end{tabular}


The distribution of knowledge of participation listed in Table 3 indicates the majority of the participants had fair knowledge about oral health. Among the participants, a positive attitude towards oral health and hygiene was comparatively less. Only $18.4 \%$ thought keeping teeth clean and healthy is beneficial to overall health and $92 \%$ felt that scaling is harmful for gums. Majority of participants (83\%) had an attitude that dentists only care for treatment and not prevention. Most participants (68\% vs. 32\%) knew sweet retention results in tooth decay. Almost half of the study population had answered correctly to the behaviour questionnaire. Only 31.9\% had experienced bleeding gums during brushing. Maximum participants (69.1\%) did routine dental check-ups. Most participants brushed teeth twice a day (65.9\%) and gave importance to teeth as much as any part of the body (69.4\%). Fifty-six percent did not have sensitive teeth (Table 3 ).

Table 3. Distribution of oral health knowledge, attitude and behaviour scores of the adult population.

\begin{tabular}{|c|c|c|}
\hline Variables & $\begin{array}{c}\text { Correct Response } \\
\text { N }(\%)\end{array}$ & $\begin{array}{c}\text { Incorrect Response / } \\
\text { I do not know } \\
\mathrm{N}(\%)\end{array}$ \\
\hline \multicolumn{3}{|l|}{ Knowledge } \\
\hline 1. There are two sets of teeth during lifetime & $252(87.5)$ & $36(12.5)$ \\
\hline 2. Tooth infection causes gum bleeding. & $237(82.3)$ & $51(17.7)$ \\
\hline 3. Replacement of missing tooth improves oral hygiene. & $231(80.2)$ & $57(19.8)$ \\
\hline 4. Dental caries of deciduous teeth need not be treated & $204(70.8)$ & $84(29.2)$ \\
\hline 5. Bacteria is one of the reasons to cause gingival problems. & $201(69.8)$ & $87(30.2)$ \\
\hline 6. Fizzy soft drinks affect the teeth adversely & $217(75.4)$ & $71(24.6)$ \\
\hline 7. Loss of teeth can interfere with speech & $229(80.0)$ & $59(20.0)$ \\
\hline 8. Irregularly placed teeth can be moved into correct position & $230(80.1)$ & $58(19.9)$ \\
\hline 9. Decayed teeth can affect appearance & $231(80.2)$ & $57(19.8)$ \\
\hline 10. Tobacco chewing or smoking cause oral cancer & $253(87.8)$ & $35(12.2)$ \\
\hline 11. White patch are called dental plaque & $243(84.3)$ & $45(15.7)$ \\
\hline Attitude & Positive & Negative \\
\hline 1. Keeping your teeth clean and healthy is beneficial to your health & $53(18.4)$ & $235(81.6)$ \\
\hline 2. Scaling is harmful for gums & $23(8.0)$ & $265(92.0)$ \\
\hline 3. Dentist care only about treatment and not prevention & $49(17.0)$ & $239(83.0)$ \\
\hline 4. Sweet retention leads to tooth decay & $196(68.0)$ & $92(32.0)$ \\
\hline 5. Brushing with fluoridated toothpaste prevent tooth decay & $217(75.3)$ & $71(24.7)$ \\
\hline 6. Brushing teeth twice a day improves oral hygiene & $199(69.1)$ & $89(30.9)$ \\
\hline 7. Gum bleeding denotes gum infection & $196(68.1)$ & $92(31.9)$ \\
\hline 8. Improper brushing leads to gum disease & $208(72.2)$ & $80(27.8)$ \\
\hline Behaviour & Adequate & Inadequate \\
\hline 1. I have bleeding gums during brushing & $92(31.9)$ & $196(68.1)$ \\
\hline 2. I do routine dental check-up & $199(69.1)$ & $89(30.9)$ \\
\hline 3. I give importance to my teeth as much as any part of my body & $200(69.4)$ & $88(30.6)$ \\
\hline 4. I brush my tooth twice daily & $190(65.9)$ & $98(34.1)$ \\
\hline 5. I use teeth to open cap of bottled drink & $122(42.4)$ & $166(57.6)$ \\
\hline 6. I have sensitive teeth & $126(43.7)$ & $162(56.3)$ \\
\hline 7. I experience toothache while chewing food & $141(48.9)$ & $147(51.1)$ \\
\hline
\end{tabular}

According to Table 4, only $2.1 \%$ had poor knowledge and $97.9 \%$ had good oral hygiene knowledge. Overall, $66.7 \%$ had a negative attitude, $33.3 \%$ had a positive attitude and $48.2 \%$ had adequate behaviour towards oral health (Table 4$)$.

The association of sociodemographic and habitual factors with knowledge, attitude and behaviour $(\mathrm{KAB})$ is presented in Table 5. Knowledge concerning education, diet, and employment was statistically significant $(\mathrm{p}<0.05)$. In addition, behaviour concerning diet and ownership of house for attitude was seen statistically significant. 
Table 4. Distribution of overall oral health knowledge, attitude, behaviour scores of adult population.

\begin{tabular}{cc}
\hline \multicolumn{1}{c}{ Variables } & N (\%) \\
\hline Knowledge & $282(97.9)$ \\
Good & $8(2.1)$ \\
Poor & \\
Attitude & $96(33.3)$ \\
Positive & $192(66.7)$ \\
Negative & $139(48.2)$ \\
Behaviour & $149(51.8)$ \\
Adequate & \\
Inadequate &
\end{tabular}

Table 5. Association of sociodemographic and habitual factors with oral health knowledge, attitude, and behaviour of adult population.

\begin{tabular}{|c|c|c|c|c|c|c|c|c|}
\hline Variables & Categories & $\mathbf{N}$ & $\begin{array}{c}\text { Knowledge } \\
\text { Median (IQR) }\end{array}$ & p-value & $\begin{array}{c}\text { Attitude } \\
\text { Median (IQR) }\end{array}$ & p-value & $\begin{array}{c}\text { Behaviour } \\
\text { Median (IQR) }\end{array}$ & p-value \\
\hline \multirow[t]{2}{*}{ Gender* } & Male & 167 & $9(7.5,10)$ & 0.96 & $4(3,5)$ & 0.59 & $4(3,5)$ & 0.69 \\
\hline & Female & 121 & $9(8,10)$ & & $4(3,5)$ & & $4(3,5)$ & \\
\hline \multirow[t]{4}{*}{ Age Group*** } & 18-24 Years & 68 & $9(8,10)$ & 0.27 & $4(3,5)$ & 0.76 & $3.5(3,5)$ & 0.35 \\
\hline & 25-34 Years & 65 & $9(7,10)$ & & $4(3,5)$ & & $4(3,5)$ & \\
\hline & $35-44$ Years & 84 & $8.5(7,10)$ & & $4(3,5)$ & & $4(3,5)$ & \\
\hline & $\geq 45$ Years & 71 & $9(7.5,10)$ & & $4(3,5)$ & & $4(3,5)$ & \\
\hline \multirow[t]{2}{*}{ Smoking* } & No & 248 & $9(7.7,10)$ & 0.16 & $4(3,5)$ & 0.42 & $3(3,4)$ & 0.29 \\
\hline & Yes & 40 & $9(8,10)$ & & $4(3,5)$ & & $4(3,5)$ & \\
\hline \multirow[t]{2}{*}{ Alcohol* } & No & 248 & $9(8,10)$ & 0.92 & $4(3,5)$ & 0.40 & $4(3,5)$ & 0.56 \\
\hline & Yes & 40 & $9(8,10)$ & & $4(3,5)$ & & $4(3,4)$ & \\
\hline \multirow[t]{2}{*}{ Marital Status* } & Yes & 192 & $9(7,10)$ & 0.28 & $4(3,5)$ & 0.65 & $4(3,5)$ & 0.17 \\
\hline & No & 96 & $9(8,10)$ & & $4(3,5)$ & & $3(3,5)$ & \\
\hline \multirow[t]{4}{*}{ Religion** } & Hindu & 237 & $9(8,10)$ & 0.49 & $4(3,5)$ & 0.31 & $4(3,5)$ & 0.99 \\
\hline & Muslim & 15 & $8(6.5,9.5)$ & & $4(3,5)$ & & $3(3,5)$ & \\
\hline & Christian & 30 & $9(8,9)$ & & $4(2.2,5)$ & & $4(3,5)$ & \\
\hline & Others & 6 & $9(7.5,9.7)$ & & $5(5,5)$ & & $4(3.2,4)$ & \\
\hline \multirow[t]{2}{*}{ Ethnicity* } & Tamil & 264 & $9(8,10)$ & 0.19 & $4(3,5)$ & 0.95 & $4(3,5)$ & 1.00 \\
\hline & Others & 24 & $9(6.7,9)$ & & $4(3,5)$ & & $4(3,4.2)$ & \\
\hline \multirow[t]{3}{*}{ Diet*** } & Vegetarian & 37 & $8(6,9)$ & $0.006^{\#}$ & $4(3,5)$ & $0.012^{\#}$ & $4(3,5)$ & 0.38 \\
\hline & Non-vegetarian & 47 & $9(7,10)$ & & $3(2,5)$ & & $3(3,4.5)$ & \\
\hline & Mixed & 204 & $9(8,10)$ & & $4(3,5)$ & & $4(3,5)$ & \\
\hline \multirow[t]{4}{*}{ Education** } & Illiterate & 7 & $8(3,9)$ & $0.009^{\#}$ & $5(2.5,5)$ & 0.52 & $4(2.5,4)$ & 0.59 \\
\hline & Primary & 12 & $8(5.7,8.2)$ & & $4(3,4)$ & & $3(2,4)$ & \\
\hline & High school & 93 & $9(8,10)$ & & $4(3,5)$ & & $4(3,5)$ & \\
\hline & University & 176 & $9(7,10)$ & & $4(3,5)$ & & $4(3,5)$ & \\
\hline \multirow[t]{4}{*}{ Employment*** } & Employed & 186 & $9(7,10)$ & $0.003^{\#}$ & $4(3,5)$ & 0.71 & $4(3,5)$ & 0.81 \\
\hline & Unemployed & 23 & $9(7,9.5)$ & & $4(4,5)$ & & $4(3,5)$ & \\
\hline & Student & 46 & $9.5(9,10)$ & & $4(3,5)$ & & $3(3,4)$ & \\
\hline & Homemaker & 33 & $8(7,9)$ & & $4(2,5)$ & & $4(3,5)$ & \\
\hline \multirow[t]{4}{*}{ Income ${ }^{* *}$} & Below 10K₹ & 98 & $9(8,10)$ & 0.65 & $4(3,5)$ & 0.65 & $4(3,5)$ & 0.10 \\
\hline & 10K₹-2OK₹ & 50 & $9(8,10)$ & & $4(3,5)$ & & $3(2,4)$ & \\
\hline & 2OK₹-30K₹ & 72 & $9(7,9.2)$ & & $4(3,5)$ & & $4(3,5)$ & \\
\hline & Above 3oK₹ & 68 & $9(7,10)$ & & $4(3,5)$ & & $4(3,5)$ & \\
\hline \multirow[t]{2}{*}{ House ${ }^{*}$} & Owned & 178 & $9(7,10)$ & 0.43 & $4(3,5)$ & 0.77 & $4(3,5)$ & $0.03^{\#}$ \\
\hline & Rented & 109 & $9(8,10)$ & & $4(3,5)$ & & $4(3,5)$ & \\
\hline \multirow[t]{2}{*}{ Vehicle* } & Yes & 182 & $9(8,10)$ & 0.85 & $4(3,5)$ & 0.13 & $4(3,5)$ & 0.98 \\
\hline & No & 106 & $9(7,10)$ & & $4(3,5)$ & & $4(3,5)$ & \\
\hline
\end{tabular}

*Kruskal Wallis Test; **Mann Whitney Test; IQR: Interquartile Range; \#Statistically Significant.

There was a poor/ weak correlation between KAB scores, and the correlation was not statistically significant (Table 6). 
Table 6. Correlation between oral health knowledge, attitude, and behaviour scores of adult population.

\begin{tabular}{ccc}
\hline Variables & Correlation Coefficient & p-value \\
\hline Knowledge-Attitude & 0.11 & 0.23 \\
Knowledge-Behaviour & -0.037 & 0.68 \\
Behaviour-Attitude & 0.01 & 0.94 \\
\hline
\end{tabular}

\section{Discussion}

Among 288 patients, the majority of the participants exhibited fairly higher knowledge on oral health and general facts. A total of $98 \%$ of participants belonged to the high knowledge group. Wahengbam et al. [17] reported that $90 \%$ of study population in Manipur had high knowledge, whereas, in a study of 858 school children in Mangalore, India, reported only $46 \%$ belonging to the high knowledge group [18]. Though the present study population exhibited a high knowledge of oral health, it did not correspond to the positive attitude and adequate oral health and hygiene behaviour. Among 288 participants, only 33\% had a positive attitude and $48 \%$ proper behaviour, which proves that the mindfulness of oral health does not necessarily influence positive attitude and adequate behaviour among people. Among 288 participants, maximum participants brushed teeth twice a day (65.9\%) and gave importance to teeth as much as any part of the body $(69.4 \%)$ and $69.1 \%$ of participants had regular oral checkups. This explains the lesser oral problems in the study population. Only $31.9 \%$ of participants had experienced bleeding gums during brushing.

In the study, only $18 \%$ considered keeping teeth clean and healthy as beneficial to overall health. But in different studies, $81 \%$ of Manipur study population, $76 \%$ of Nepal children, and $93 \%$ of Iranian children had believed that keeping teeth clean and healthy is beneficial to overall health $[17,19,20]$.

Regarding sociodemographic and habitual variables, age, gender, and lifestyle (smoking, consuming alcohol, religion, and ethnicity) did not affect the participants' knowledge, attitude, and behaviour. On the other hand, earlier studies had reported females showed better oral care practice than males; however, the knowledge and attitude were not affected by gender significantly [17,21,22]. Diet of the participants did significantly affect the knowledge and behaviour score with greater scores for participants with mixed diets and lesser scores for a vegetarian diet.

Nevertheless, it did not affect the behaviour of the participants significantly. Education and employment of the participants had shown a significant effect on the knowledge score of participants. Participants with high school and university levels of education had higher knowledge scores than participants who were illiterates. This specifies the importance and role of education in oral health. Similar findings were reported in several other studies [17,23-25].

It was also seen that student and employed participants had statistically significantly higher knowledge scores than homemakers and unemployed participants. Homemakers had comparatively lower knowledge scores. The correlation revealed non-significant weak correlations between knowledge-attitude $(\mathrm{r}=0.11, \mathrm{p}<0.21)$ knowledge-behaviour $(\mathrm{r}=-0.037, \mathrm{p}<0.68)$ and attitude-behaviour $(\mathrm{r}=0.01 \mathrm{p}<0.91)$. The correlation assessment indicates that the mere knowledge of oral health does not necessarily influence people's positive attitudes and adequate behaviour.

Our current study has some limitations. As our study is cross-sectional, it is difficult to identify the causal direction of oral health knowledge, attitude, and behaviour towards oral health. In addition, contextual variables were not taken into account as study participants changed of address. To add upon, individuals who were physically, mentally, or legally incapacitated, so that informed consent to treat cannot be obtained were not included in our study. Exploring the level of oral health knowledge, attitude, and behaviour at the proper 
time frame would help achieve an ideal improvement of oral hygiene among the population by establishing a better oral health care promotion and policy based on the study outcome.

\section{Conclusion}

Although individuals with a good level of knowledge towards oral health had inadequate attitude and behaviour towards oral health, which is basically due to least importance they give towards their oral health. Our findings shed light on the imbalance of oral health attitude and behaviour, regardless of better oral health knowledge. Furthermore, we insist the concerned authorities develop ideal oral health promotion and services that would help provide a better insight into the importance of oral health among individuals to maintain better oral hygiene. Our study findings might fill the vacuum and help to give a proper idea to formulate evidence-based oral health reinforcement programs to minimize the disparity between knowledge, attitude, and behaviour towards oral health.

\section{Authors' Contributions}

\begin{tabular}{|c|c|c|}
\hline SS (ic & https://orcid.org/0000-0002-7776-3335 & $\begin{array}{l}\text { Conceptualization, Methodology, Formal Analysis, Investigation, Writing - Original Draft and } \\
\text { Writing - Review and Editing. }\end{array}$ \\
\hline NNN & https://orcid.org/0000-0001-8308-5625 & Conceptualization, Methodology, Formal Analysis and Writing - Review and Editing. \\
\hline NWA ID & https://orcid.org/0000-0002-4265-442X & Conceptualization, Methodology, Formal Analysis and Writing - Review and Editing. \\
\hline MHGA iD & https://orcid.org/0000-0001-8794-5725 & Conceptualization, Methodology, Formal Analysis and Writing - Review and Editing. \\
\hline
\end{tabular}

\section{Financial Support}

None.

\section{Conflict of Interest}

The authors declare no conflicts of interest.

\section{Data Availability}

The data used to support the findings of this study can be made available upon request to the corresponding author.

\section{References}

[1] Siddharthan S, Naing NN, Wan-Arfah N, Assiry AA, Adil AH. Oral health and services in India. Int J Pharm Res 2021; 13(1):3786-3790. https://doi.org/10.31838/ijpr/2021.13.01.590

[2] Assiry AA, Siddharthan S, Adil AH, Naing NN. Periodontal disease among Saudi Arabia and South Asian developing nations. Int J Pharm Res 2021; 13(2):565-70. https://doi.org/10.31838/ijpr/202 1.13.02.114

[3] Selvaraj S, Naing NN, Wan-Arfah N, Abreu MHNG. Demographic and habitual factors of periodontal disease among South Indian adults. Int J Environ Res Public Health 202 1; 18(15):7910. https://doi.org/10.3390/ijerph 18157910

[4] Selvaraj S, Naing NN, Wan-Arfah N. Effect of periodontal health in marital life. Res J Pharm Technol 2021; 14(8):4463-5. https://doi.org/10.52711/0974-360X.2021.00775

[5] Friedman LA, Mackler IG, Hoggard GJ, French CI. A comparison of perceived and actual dental needs of a selected group of children in Texas. Comm Dent Oral Epidemiol 1976; 4(3):89-93. https://doi.org/10.1111/j.1600-0528.1976.tb02 104.x

[6] Malik S, Kamra S, Bhardwaj A. Knowledge, attitude and behavior towards oral health among teaching staff members of non-medical faculties in higher education institution with multiple faculties. Ann Romanian Soc Cell Biol 2021; 25(6):13260-81.

[7] Diwan S, Saxena V, Bansal S, Kandpal SD, Gupta N. Oral health: knowledge and practices in rural community. Indian J Comm Health 2011; 22(2):29-33.

[8] Grewal N, Kaur M. Status of oral health awareness in Indian children as compared to Western children: A thought provoking situation (a pilot study). J Indian Soc Pedod Prev Den 2007; 25(1):15-9. https://doi.org/10.4103/0970-4388.31983

[9] Ahamed S, Moyin S, Punathil S, Patil NA, Kale VT, Pawar G. Evaluation of the oral health knowledge, attitude and behavior of the preclinical and clinical dental students. J Int Oral Health 2015; 7(6):65-70. 
[10] Nutbeam D. Health literacy as a public health goal: A challenge for contemporary health education and communication strategies into the 21st century. Health Promot Int 2000; 15(3):259-67. https://doi.org/10.1093/heapro/15.3.259

[11] Lee JY, Rozier RG, Lee SY, Bender D, Ruiz RE. Development of a word recognition instrument to test health literacy in dentistry: the REALD-30 - a brief communication. J Public Health Dent 2007; 67(2):94-8. https://doi.org/10.1111/j.1752-7325.2007.00021.x

[12] Elanchezhiyan S, Raja. Awareness on gingival health among orthodontic correction seeking individuals. J Indian Acad Dent Spec Res 2010; 1(3):19-21.

[13] Polychronopoulou A, Kawamura M, Athanasouli T. Oral self-care behavior among dental school students in Greece. J Oral Sci 2002; 44(2):73-8. https://doi.org/10.2334/josnusd.44.73

[14] Selvaraj S, Naing NN, Wan-Arfah N, Prasadh S. Confirmatory factor analysis of knowledge, attitude, and behaviour questionnaire towards oral health among Indian adults. J Pers Med 2021; 11(4):320. https://doi.org/10.3390/jpm 11040320

[15] Marya A, Karobari MI, Selvaraj S, Adil AH, Assiry AA, Rabaan AA, et al. Risk perception of SARS-CoV-2 infection and implementation of various protective measures by dentists across various countries. Int J Environ Res Public Health 202 1; 18(11):5848. https://doi.org/10.3390/ijerph 18115848

[16] Siddharthan S, Naing NN, Wan-Arfah N. Periodontal disease and COVID 19. J Pharm Res Int 2020; 32(32):88-91. https://doi.org/10.9734/jpri/2020/v32i3230937

[17] Wahengbam PP, Kshetrimayum N, Wahengbam BS, Nandkeoliar T, Lyngdoh D. Assessment of oral health knowledge, attitude and self-care practice among adolescents - a state wide cross-sectional study in Manipur, North Eastern India. J Clin Diagn Res 2016; 10(6):ZC65-ZC70. https://doi.org/10.7860/JCDR/2016/20693.8002

[18] Suprabha BS, Rao A, Shenoy R, Khanal S. Utility of knowledge, attitude, and practice survey, and prevalence of dental caries among 11- to 13-year-old children in an urban community in India. Glob Health Action 2013; 6:20750. https://doi.org/10.3402/gha.v6io.20750

[19] Prasai Dixit L, Shakya A, Shrestha M, Shrestha A. Dental caries prevalence, oral health knowledge and practice among indigenous Chepang school children of Nepal. BMC Oral Health 2013; 13:20. https://doi.org/10.1186/1472-6831-13-20

[20] Rad M, Shahravan A, Haghdoost AA. Oral health knowledge, attitude, and practice in 12-year-old schoolchildren in Iran. J Int Soc Prev Community Dent 2015; 5(5):419-24. https://doi.org/10.4103/2231-0762.165926

[21] Kassak KM, Dagher R, Doughan B. Oral hygiene and lifestyle correlates among new undergraduate university students in Lebanon. J Am Coll Health 2001; 50(1):15-20. https://doi.org/10.1080/07448480109595706

[22] Tada A, Hanada N. Sexual differences in oral health behaviour and factors associated with oral health behaviour in Japanese young adults. Public Health 2004; 118(2):104-9. https://doi.org/10.1016/j.puhe.2003.05.007

[23] Smyth E, Caamaño F, Fernández-Riveiro P. Oral health knowledge, attitudes and practice in 12-year-old schoolchildren. Med Oral Patol Oral Cir Bucal 2007; 12(8):E614-E620.

[24] Cheung J, Lee TK, Teh CZ, Wang CY, Kwan WC, Yoshida EM. Cross-sectional study of hepatitis B awareness among Chinese and Southeast Asian Canadians in the Vancouver-Richmond community. Can J Gastroenterol 2005; 19(4):245-9. https://doi.org/10.1155/2005/583406

[25] Wu CA, Lin SY, So SK, Chang ET. Hepatitis B and liver cancer knowledge and preventive practices among Asian Americans in the San Francisco bay area California. Asian Pac J Cancer Prev 2007; 8(1):127-34. 